\title{
Mandatory audit firm rotation: A student perspective An assessment of the perceived impact on auditor independence
}

\author{
Msizi Gwala, Bomi Cyril Nomlala* \\ College of Law \& Management Studies, University of KwaZulu-Natal, South Africa \\ *Corresponding author: nomlalabc@ukzn.ac.za
}

A R T ICLE IN F O

A B S T R A C T

Article history:

Available online

Keywords:

Mandatory Audit Firm Rotation,

$M A F R$, auditor independence,

auditor rotation

DOI:

https://doi.org/10.20885/jaai.vol25.i

ss1.art1
Mandatory Audit Firm Rotation (MAFR), set to be implemented in South African from 1 April 2023, is poised by its propellers the world over as an essential reform in the efforts to improve auditor independence. Available literature suggests that there is no consensus regarding the impact of the implementation of MAFR. The divergent views on MAFR were demonstrated in recent time, with the European Union (EU) choosing to adopt it, while regulators in the United States decided to reject it. This paper examines the perspective of university auditing students on MAFR by examining the perceived impact it could have on auditor independence. The study finds that the majority (from 413 participants) of students surveyed are of the view that MAFR would yield positive outcomes on independence. The majority, however, agree on the MAFR Independence Benefit but warn about the possible negative consequences. MAFR will strengthen the independence of auditors.

\section{Introduction}

It appears as though the jury is still out on whether MAFR should be implemented or not. This, as no clear consensus, has been reached on the ongoing world debate on the benefits and disadvantages of the implementation of this audit reform. The appropriateness of the implementation of the MAFR rule remains under dispute as proponents and opponents of the rule outline the benefits and negative impact the rule brings. Notwithstanding the current discourse, the Independent Regulatory Board for Auditors (IRBA) of South African issued through a board notice in accordance with the Auditing Profession Act, 26 of 2005 the rule on MAFR, which will come into effect on 1 April 2023 for South African auditors. According to the rule, an audit firm auditing a Public Interest Entity (PIE) shall not accept re-appointment as auditor after having served for ten consecutive years IRBA (2017). The South African Institute of Chartered Accountants (SAICA) and the accounting profession (represented mainly by audit firms) are against the implementation of this rule in its current form (SAICA, 2017; SAICA Indaba, 2016), citing amongst other issues that available research does not conclusively support the implementation of MAFR.

This study seeks to determine whether or not, according to university auditing students, the intended implementation of the MAFR rule in South Africa will result in benefits for the auditing profession and the country based on their considered impact on auditor independence. Current students are an essential consideration and stakeholder in discussions around the introduction of the MAFR rule as they will be amongst the first audit teams to be affected by the implementation of the rule when it becomes effective.

The IRBA has decided on the date for the implementation of MAFR despite the objections put forward by SAICA (together with the accounting profession and some stakeholders in general (SAICA 2017; SAICA MAFR Indaba 2016). Reasons put forward to justify the implementation of MAFR by IRBA have been challenged by those against this rule. One of the objections was that the results of the research on the effects of MAFR are mixed, not necessarily favouring its implementation (Ewelt-Knauer et al., 2013; Junaidi et al., 2016; Stern, 2015). The IRBA is of the view that MAFR will improve the independence of auditors, which it believes is somewhat compromised by the long audit tenures. The IRBA had also considered the effect that MAFR could have on audit quality, the transformation of the profession and the de-concentrate of the audit market IRBA (2017). This study examines the perceptions of future auditors (currently university students) about the implementation of MAFR based on their perceptions on its impact on independence which is cited by the IRBA as a key reason for the introduction of MAFR.

The objective of this study is to determine the perception of university auditing students about the MAFR rule issued and prescribed by the IRBA for auditors of public interest entities. The study seeks to determine whether or not they perceive that the auditing profession will reap the intended benefit of enhanced auditor independence from the introduction and implementation of MAFR or whether there could be unintended negative consequences resulting from the rule. 
The study provides insights into the views of future auditors on the MAFR rule that is set to be implemented in 2023. These perceptions can assist regulators and decision-makers to reflect on the matter of MAFR in South Africa and provide information that can be considered in future developments. While many different stakeholders can contribute to the matter, university students add unique value. The student population is primarily comprised of younger millennials (primarily 18 to 21 years of age for this study) who, according to the theory of generations as developed by Howe and Strauss, are different to the baby boomers and generation (Howe \& Strauss, 1993; Pew Research Center, 2010). Millennials are considered amongst other things to be self-assured, self-expressive and open to new things and ways Pew Research Center (2010) and this study can place them in a position to help shape or influence the future of the auditing profession. Furthermore, some of these students will be amongst the first audit teams to be affected by the rule when implemented.

Getting student's views on the future concept/procedure is well-known phenomena that is widely often used both in academia and in industry. This concept was explored again by Walker et al. (2017) used; this concept in order to understand the impact of a new palliative care approach planned in the future by asking future doctors about their views, which their gained insight on this views of future doctors. Similarly to other studies Bals et al. (2019) through their study used students in purchasing and supply management(PSM)to understand competencies needed for future PSM and their results proved beneficial in gaining some insights of the needs of the future.

\section{Literature Review}

In the long history of the development of Auditing, including changes in objectives from the traditional role of testing conformance, to the more recent enhancing, value-adding and convergence roles, independence requirements and expectations have also changed and will continue to in future as the auditing profession and practice evolve (TeckHeang \& Ali 2008; Church et al. 2015). The introduction of the MAFR is considered to be a response to the "perceived" decline in the independence of auditors which is at the core of the auditing function (IRBA, 2017). The IRBA CPC, which describes the fundamental principles within which auditors work puts the independence of auditors at the centre of the auditing profession as a fundamental "must-have" in order to be able to conduct an audit as required (IRBA 2009; Tanlu et al. 2003; Quick 2012; Hussey 1999; Dezoort \& Taylor 2015). This makes the need for auditor independence (both in mind and appearance) to be foundational to Auditing (Harber 2016; Tanlu et al. 2003; Quick 2012; Hussey 1999; Dezoort \& Taylor 2015). In a more recent study on MAFR, the practitioners have also alluded to the importance of independence as a critical aspect to MAFR (Harber \& Maroun, 2020).

Continuing auditor-client relationships can lead to auditor complacency and undue trust of the client which threaten their independence (Church et al., 2015). The IRBA CPC identifies familiarity as being one of the threats to compliance with independence requirements IRBA (2009a). Familiarity, which provides a social incentive to the auditor, causes auditors to identify with the client and affects their judgement Bamber and lyer (2007). This is, however, mitigated by the auditor's professional identification and evidence that long audit tenures lead to greater objectivity and independence, not less Bamber and Iyer (2007). Furthermore, there seems to exist a premise ensuing from the concept of risk-based Auditing outlined in the International Auditing Standards (ISAs) that familiarity with the audit client may be needed in order for the auditor to understand the client well enough to plan and execute a proper and well-organised audit (Bamber \& Iyer, 2007).

The familiarity threat is more powerful at the auditor appointment stages, where directors (including former) have influence over decisions. Though classified as "professional and amicable", relationships are considered during auditor appointment. The performance of non-audit work does not have as significant an impact on the familiarity threat as is commonly perceived Dhaliwal et al. (2015) and Hussey (1999). Besides the familiarity threat, auditors may also have their independence affected by conflict founded in the role conflict theory. Auditors have numerous authorities and professional values or expectations, which could affect their objectivity (Rizzo et al. 1970 ; Teck-Heang \& Ali 2008). Role conflict could arise as auditors need to meet the expectations of the regulatory body (IRBA), various stakeholders, which include management, shareholders and those external to their clients.

The available research on MAFR shows mixed results, both in favour and against its implementation (Ewelt-Knauer et al., 2013; Junaidi et al., 2016; Stern, 2015), which has caused different jurisdictions to take clashing stands in the legislation of auditor rotation, with some opting not to implement it at all. The IRBA's decision to implement MAFR in South Africa follows the introduction of regulatory audit reform by the European Union (EU), which included the adoption of MAFR. This, after consideration of the same regulation and rejection by regulators in the United States (US) (Tysiac, 2014). Proponents of MAFR (which include the IRBA) consider the current measures (provided by company law and the CPC), which include oversight by the audit committee and audit partner rotation, to be insufficient to mitigate concerns over auditor independence.

In support of MAFR, concerns were raised about the "cosy" relationship between Enron and its Arthur Anderson auditors, who seemingly became too familiar, leading to the well-documented failure of both (Arel et al., 2005). Regulators have expressed concerns over the lack of independence in the conduct of audits and continue with efforts or intentions to introduce appropriate safeguards, such as MAFR (Church et al., 2015). 
The MAFR rule is being introduced mainly because of the need to strengthen the independence of auditors (IRBA 2017a; IRBA 2017c), which has declined over time due to some factors Hodge (2003) and is in the interest of the public. It is debatable, however, whether the regulation is indeed underpinned by the public (business, economy, stakeholders, society, etc.) or private (power, prestige, public standing, perception, etc. of the IRBA or interest groups) interests. This as some are of the opinion that the regulation is not the correct solution to the problem - if there is indeed a problem (SAICA 2017; SAICA Indaba 2016; Center for Audit Quality 2012; Harber 2016; Ottaway 2013; Asian 2012; AICPA 2017). The regulation of the auditing profession is not straight forward. It is dynamic and is not necessarily the exclusive responsibility of governments and regulators. The profession, to an extent (notwithstanding the Auditing Profession Act No. 5 of 2005), regulates its operation without law through bodies such as the International Auditing and Assurance Standards Board (IAASB) of the International Federation for Accountants (IFAC).

In the public interest, the costs that would be incurred in the creation of "true independence" are worthwhile and improved regulation which includes MAFR, is a viable solution to the issue Tanlu et al. (2003). Independence, while important, is inconsistent and unclear (Church et al. 2015; Malsch et al. 2015; Tepalagul \& Lin 2015); for example, currently, the client must financially compensate its auditors, a set up that renders true and complete independence virtually impossible Dezoort \& Taylor (2015). The auditors' working independence (the fitness to work thoroughly and effectively in order to identify material irregularities) is not only unsettled in practice, but it is also uncertain, often ignored (over institutional independence) and not easy to attain (Malsch et al., 2015).

Most auditors concur that MAFR could protect the independence of auditors Said and Khasharmeh (2014). Auditors, however, have an incentive to protect their reputation and this would lead to their issue of a going concern modified opinion Ruiz-Barbadillo et al. (2009), compared to the view that they are would sacrifice their independence in long tenure audit engagements to issue modified audits opinions (other than going concern modification where they would not compromise) (Garcia-Blandon \& Argiles, 2015). This is a demonstration of the differing views on independence and long tenures.

Harber (2016), found that according to senior audit partners in South Africa, it is only the perception of the public that independence is compromised and to which the IRBA is presumably responding. This is not necessarily the same as the reality of the state of independence, which the study concludes should be responded to through improved corporate governance practices (not MAFR) Harber (2016). Anis (2014), however, similarly to Said and Khasharmeh (2014) in a survey of auditors found that generally, auditors agree that mandatory rotation would improve both the independence of the auditor in mind and appearance. This supports a previous study by Pearson (1987) who surveyed United States CPAs practising as independent auditors. The results of this study indicated that auditors believed independence had been impaired with some admitting to personal experiences.

Long audit tenure has an adverse effect on the independence of auditors and auditor rotation has a positive one. This means that auditor rotation improves the independence of auditors. The size and age of the auditee, as well as the reputation of the auditors, have no influence on the independence of auditors (Junaidi et al., 2016). MAFR regulation helps maintain independence and is needed. An artificial rotation of auditors (conceptual change of auditors with the relationship in actual fact continuing) has a significant negative impact on auditor independence (Junaidi et al., 2016).

An analysis of investor and market reaction to the prospects of the introduction of MAFR demonstrates negativity towards the proposal (Reid \& Carcello, 2017). However, non-professional investors perceive auditor independence to have declined over time, resulting in the perceived drop in the reliability of audited financial statements, although their use had increased Hodge (2003). Furthermore, investors perceive auditor independence to be impaired (specifically) as a result of a lengthy audit tenure (without rotation) and thus supporting the argument for the introduction of MAFR but highlight the importance of industry-specific knowledge in order to maintain adequate audit quality (Hohenfels, 2016). This is in contrast to the perception of investment consultants according to whom MAFR leads to no improvement in auditor independence (Aschauer \& Quick, 2018). Bank loan officers also support a voluntary audit firm rotation policy, according to Daniels and Booker (2011). The officers believe that rotation increases auditor independence, although they were not too concerned by the period of rotation and did not associate it with any improvement in quality Daniels \& Booker (2011). Improving the quality of auditing services by increasing auditor independence is a win-win situation. Auditor independence must be preserved, especially when it comes to audit fees. According to Zhang et al. (2016), the level of audit fees does not indicate a lack of independence. Higher audit costs, on the other hand, lead to more effective audit services as compared to organizations with lower audit costs (Khan \& Subhan, 2019).

\section{Research Method}

The decision over a method was dependent on the context of the study, considering the topic, characteristics of the participants (students) and availability of resources (Floyd \& Fowler, 2009). In this study, the researcher followed a post-positivist research paradigm which, accordingly, informs the quantitative approach in addressing the 
objectives. The purpose of the study was to understand the student perspectives on the effects of the MAFR rule on independence to be implemented in 2023 and make predictions based on findings. A quantitative approach was used by the researcher to do this, gauging where the future auditors (university students) stand on MAFR. The quantitative research method was suitable in studies that indicate trends and explain relationships between variables (Creswell, 2014). Data was collected from the target population, comprising students at the two higher education institutions (University of KwaZulu-Natal - UKZN and the University of Zululand - UNIZULU) who are participants in the study. The participants are currently registered for an auditing course (or module) in the Bachelor of Commerce (Accounting), Bachelor of Accounting Science or the Postgraduate Diploma in Accounting (PGDA). These accounting qualifications follow the competency framework of the South African Institute of Chartered Accountants (SAICA).

For the (UNIZULU), a total of 282 students were identified for the study (230 for Auditing 3 and 52 for Auditing 4). A total of 1337 students were identified at the (UKZN) (498 for Auditing 200, 444 for Auditing 300 and 395 for Advanced Auditing). The sum for the study was thus 1619 (281 plus 1337). A non-probability sampling technique has been used to select participants for the study. Non-probability sampling was used as some judgement needed to be exercised in conducting the study, a non-random approach to sampling was followed (Blair et al., 2014). The sample was comprised of students who were in attendance during a pre-selected auditing lecture slot. To limit bias, students were not informed prior to conducting the research of the intention. The selection of the lecture period was random and dependent only on logistical arrangements and availability of time immediately before or after the period.

Similar to Said and Khasharmeh (2014) and Anis (2014), who used survey questionnaires to solicit the perceptions of auditors regarding MAFR from participants, data were collected from participants using a questionnaire. Given the context and nature of the study, whose participants are current university students, structured questionnaires were more appropriate than, for example, an interview (which would require greater insights by the participants). The first section (General information) of the questionnaire requires participants to complete their biographic information such as age, gender, race, level of study, etc. and comprises a total of six (6) questions. The second section (MAFR questionnaire) relates to the research question and is informed by literature. It contains five (5) questions relating to the impact of MAFR on independence. An open question has been included in the second section of the questionnaire, which requires participants to mention any potential impact of MAFR not mentioned in the questionnaire, without changing the methodology (Hofstee, 2006). From this open question, the study identified common themes on independence from the responses of participants.

From the data analysis and based on observations during the data collection process, students were discussing different views on MAFR and able to respond to the research questions with no issues noted. This illustrates their ability to respond to the survey questions, increasing confidence in the degree to which the study measures the perceptions of students on MAFR (Creswell 2014; Saunders et al. 2009). The questionnaire was reviewed by the Head of Auditing at UNIZULU and a pilot study was conducted with Auditing tutors at the same university, with feedback incorporated into the questionnaire. The alpha calculated for the study is 0.82 , which was considered to be good (Hair et al., 2007), thus indicating that a reliable instrument has been used. Auditing university students (who constitute the population for this study) at traditional universities (particularly throughout the country, similar to those in this study) are gradually working through formal competency-based academic education (in South Africa, a SAICA academic programme). The SAICA academic programme was navigated in a similar manner by different universities, and ultimately, students exit at competency levels that are the same (SAICA, 2016). The results of the study thus may be generalisable. Once complete and accurate data for the study were collected, an analysis to explain data was performed and inferences by using appropriate statistical techniques (descriptive and inferential) or were made (Kumar, 2012).

Demographical characteristics of the variables were also tested to examine the different contributions to the study; of importance was the role of the demographic characteristics to students studying in the two different Universities, namely, UNIZULU and UKZN. The examined literature also looked at the role demographical characteristics will have on the mandatory audit rotation. In this study, the standard deviation (which measures the average distance of each value away from the sample mean) has been used to describe as well as compare the difference between the mean and values provided by respondents (Cresswell, 2014; Saunders et al., 2009).

According to the literature reviewed, Pearson correlation should be used to investigate the role of race, age, level of research, and university location of respondents in determining independence. The study's importance is in gaining a better understanding of students' expressions or perspectives on the critical principle of MAFR. The Pearson correlation coefficient ( $r$ ) can range from -1 (negative relationship) to +1 (positive relationship) (positive relationship). A coefficient of -0.3 or 0.3 is considered poor, while a value of 0 indicates complete independence of the variables. 


\section{Results and Discussion}

The results of the analysis and discussion of the 413 questionnaires completed by auditing students at the Universities of Zululand and KwaZulu-Natal are presented below. A sample size of 439 was determined for the study, using a $4 \%$ margin of error and a confidence level of 95\%. This (413 questionnaires) represents a response rate of $94 \%$. The questionnaires were handed out to students during or around the time of their auditing lectures at the respective university. The objective of the study was to examine the perception of auditing students regarding the imminent implementation of MAFR in South Africa and the impact it will have on independence

In analysing the data, descriptive and inferential statistics were used to identify frequencies, percentages of responses to questions and the general perception of respondents. The measure of central tendency (expressed as a mean) and the variability measure (the standard deviation) have been used in the analysis. The data and findings are discussed according to the following sections, in line with the questionnaire used to collect data; 1) Personal (Biographical) data, 2) Impact on auditor independence, 3) Additional comments by students.

The research instrument utilised in the study (refer to appendix A) is consistent, based on literature and contains clear questions and response options. Based on the data analysis (and observations during the data collection process), students were able to respond to the research questions correctly, with no issues noted. Furthermore, students were observed discussing views on the different MAFR issues, illustrating their ability (and interest) to respond to the survey questions. We are confident that the study has met its objectives. Regarding sample selection, the approach followed was based on students who were in attendance during auditing lectures on a randomly pre-selected day (no prior arrangements were made with students). This makes it possible to generalise the findings.

\section{Descriptive Statistics}

This section covers the respondents' age, race, gender, university of study, level of study and qualification registered for. Though not central to the study, this section helps contextualise the results by providing a profile of the respondents.

Table 1. Total Respondents for the Study

\begin{tabular}{lcccccc}
\hline & Age & Race & Gender & University of study & Qualification registered & Level of study \\
\hline Valid & 404 & 412 & 413 & 413 & 413 & 413 \\
Missing & 9 & 1 & 0 & 0 & 0 & 0 \\
Total & 413 & 413 & 413 & 413 & 413 & 413 \\
\hline
\end{tabular}

Respondents were asked their age, gender, university of study, qualification registeredfor as well as the level of study. Tables 2 to 5 depict this information.

Table 2. Age and Gender

\begin{tabular}{lcc}
\hline Age and Gender & Frequency & Percentage \\
\hline $18-21$ & 276 & 68.3 \\
$22-25$ & 115 & 28.5 \\
$26-30$ & 13 & 3.2 \\
Total & 404 & 100 \\
Male & 196 & 47.5 \\
Female & 217 & 52.5 \\
Total & 413 & 100.0 \\
\hline
\end{tabular}

Table 3. Race and University of study

\begin{tabular}{lcc}
\hline Race and University & Frequency & Percentage \\
\hline African & 314 & 76.2 \\
Coloured & 9 & 2.2 \\
Indian & 83 & 20.1 \\
White & 5 & 1.2 \\
Other & 1 & 0.2 \\
Total & 412 & 100.0 \\
University of Zululand & 150 & 36.3 \\
University of KwaZulu-Natal & 263 & 63.7 \\
Total & 413 & 100 \\
\hline
\end{tabular}


Table 4. Qualification Registered at University

\begin{tabular}{lrr}
\hline Qualification Name & Frequency & Percentage \\
\hline UNIZULU - Bachelor of Accounting Science & 72 & 17.4 \\
UNIZULU - Bachelor of Accounting & 78 & 18.9 \\
UKZN - Bachelor of Accounting & 237 & 57.4 \\
UKZN - Postgraduate Diploma in Accounting & 26 & 6.3 \\
Total & 413 & 100.0 \\
\hline
\end{tabular}

Table 5. Level of study

\begin{tabular}{lcc}
\hline Level of study & Frequency & Percentage \\
\hline 2 (UKZN) & 137 & 33.2 \\
3 (UKZN and UNIZULU) & 214 & 51.8 \\
4 (UNIZULU NON-CTA) & 36 & 8.7 \\
4 (UKZN CTA) & 26 & 6.3 \\
Total & 413 & 100.0 \\
\hline
\end{tabular}

Section A of the questionnaire revealed that out of the 413 respondents to the study, most are between the ages of 18 and $21(68.3 \%)$, female (52.5\%), African (76.2\%), registered at the University of KwaZulu-Natal $(63.7 \%)$, registered (at UKZN) for the Bachelor of Commerce (Accounting) degree (57.4\%) and in their third year of study $(51.8 \%)$.

\section{The Impact of MAFR on Independence}

This section of the questionnaire reveals responses of students on questions relating to the perceived effect of MAFR on independence. The questions were answered by students using the Likert scale (between one and five).

Table 6. Responses Relating to MAFR Impact on Auditor Independence

Statements relating to the perceived impact of the implementation of MAFR on independence.

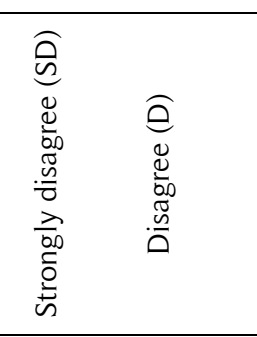

Q7. A long audit tenure (term), where an audit firm audits a client longer than ten years without rotating leads to the familiarity threat to the independence of the auditor.

Q8. A long audit tenure (term), where an audit firm audits a client longer than ten years without rotating leads to the compromise of the professional scepticism of the auditor.

Q9. A long audit tenure (term), where an audit firm audits a client longer than ten years without rotating will cause the auditor to be sympathetic to the position of the audit client.

Q10. A long audit tenure (term), where an audit firm audits a client longer than ten years without rotating leads to the compromise of the objectivity of the auditor.

Q11. The implementation of MAFR will lead to the enhancement of the independence of auditors when conducting an audit.

\begin{tabular}{lllllll}
2.9 & 1.2 & 2.7 & 24.5 & 68.8 & 4.55 & .851 \\
1.7 & 4.6 & 11.7 & 40.4 & 41.6 & 4.16 & .921 \\
3.2 & 3.9 & 15.3 & 34.5 & 43.1 & 4.19 & .923 \\
1.9 & 4.1 & 10.9 & 39.6 & 43.4 & 4.11 & 1.01 \\
& & & & & & \\
2.7 & 1.2 & 5.8 & 28.3 & 62.0 & 4.46 & .871 \\
\hline
\end{tabular}

Students responded positively (agree or strongly agree) to all five questions relating to the impact of MAFR on auditor independence (with an average mean above 4).

When asked if long audit tenures (over 10 years) lead to the familiarity threat to auditor independence, the majority of students (93.3\%) affirmed, with a mean of 4.55 and standard deviation of 0.851 , which confirms this view. This result is in line with the IRBA CPC, which identifies the long association with audit clients as a threat to independence (IRBA, 2009). This finding is also consistent with (Hussey, 1999) who found that a longer audit term does threaten independence.

The majority of respondents (82\%) affirmed when asked if a long audit tenure leads to the compromise of the professional scepticism of the auditor. This was confirmed by a mean of 4.16 and a relatively low standard deviation of 0.921 . On long tenures resulting in auditors being sympathetic to the position of their client, the 
majority (78.5\%) affirmed, with a mean of 4.19 and a standard deviation of 0.923 . Garcia-Blandon and Argiles (2015), consistent with these results, found that auditors were more inclined to sacrifice their independence and scepticism in long tenure audit engagements. Bamber \& Iyer (2007) finds that auditors indeed identify with their clients in varying levels, however auditors do consider their professional identity as important. Svanberg and Öhman (2015) also found that auditors are inclined to identify with their clients, and when they do, there could be compromised scepticism and preferential treatment.

Respondents were asked if a long audit tenure leads to compromised auditor objectivity. The majority (83\%) affirmed with a mean of 4.11 and a standard deviation of 1.01. This is consistent with the findings of (GarciaBlandon \& Argiles-Bosch, 2017) that tenure has an effect on auditors identifying with clients and which impairs auditor objectivity. When asked the direct question of the impact of the implementation of MAFR on independence, the majority of the respondents $(90.3 \%)$ responded positively that its implementation will lead to enhanced auditor independence. The mean confirms the strength of the positive response $($ mean $=4.46)$ and with a standard deviation of 0.871. This is consistent with Junaidi et al. (2016) and Hohenfels (2016) who found a positive relationship between audit firm rotation and auditor independence.

Inferential Statistics

Table 7. Pearson's correlation

\begin{tabular}{cccccc}
\hline $\begin{array}{c}\text { Statements relating to the perceived impact of the } \\
\text { implementation of MAFR on independence. }\end{array}$ & Q7 & Q8 & Q9 & Q10 & Q11 \\
\hline Q7. & 1 & & & & \\
Q8. & $.556^{* *}$ & 1 & & & \\
Q9. & $.584^{* *}$ & $.459^{* *}$ & 1 & & \\
Q10. & $.467^{* *}$ & $.446^{* *}$ & $.587^{* *}$ & 1 & 1 \\
Q11. & $.459^{* *}$ & $.287^{* *}$ & $.351^{* *}$ & .186 & 1 \\
\hline
\end{tabular}

**. Correlation is significant at the 0.01 level (2-tailed).

*. Correlation is significant at the 0.05 level (2-tailed).

Four correlation coefficients were assessed using Pearson's correlation for responses on the impact on auditor independence and all relationships between variables were considered to be statistically significant $(p<0.05)$ indicating a positive relationship between all responses on independence by students, confirming the general view by respondents that the implementation of MAFR will improve auditor independence. The majority of the relationships reflect can be accepted as a medium with two being weak and below 0.3 .

The following analysis provides some insights into the responses provided by different respondents on question 11 (The implementation of MAFR will lead to the enhancement of the independence of auditors when conducting an audit). Responses are analysed by race, age group, university and level of study. Questions 11 has been selected as it is most adequate to provide the perceptions of students on the impact of MAFR on independence.

Table 8. Analysis of Race Vs MAFR Enhancing Auditor Independence

\begin{tabular}{lrrrrrr}
\hline & SD & D & N & A & SA & Total \\
\hline African & 7 & 2 & 20 & 91 & 194 & 314 \\
Coloured & 0 & 0 & 0 & 4 & 5 & 9 \\
Indian & 4 & 3 & 2 & 19 & 55 & 83 \\
White & 0 & 0 & 2 & 3 & 0 & 5 \\
Other & 0 & 0 & 0 & 0 & 1 & 1 \\
Total & 11 & 5 & 24 & 117 & 255 & 412 \\
\hline
\end{tabular}

A consistently high percentage of the different races (African: 90.8\%, Coloured: 100\% and Indian: $89.2 \%$, other: $100 \%$ and White (slightly lower): $60 \%$ ) agreed that MAFR would enhance auditor independence.

Table 9. Analysis of Age Vs MAFR Enhancing Auditor Independence

\begin{tabular}{lrrrrrr}
\hline & SD & D & N & A & SA & Total \\
\hline $18-21$ & 10 & 4 & 15 & 73 & 174 & 276 \\
$22-25$ & 1 & 1 & 8 & 37 & 68 & 115 \\
$26-30$ & 0 & 0 & 1 & 4 & 8 & 13 \\
Total & 11 & 5 & 24 & 114 & 250 & 404 \\
\hline
\end{tabular}

A consistently high percentage of the different age groups (18-21: 89.5\%, 22-25: $91.3 \%$ and $26-30$ : 92.3\%) agreed that MAFR would enhance auditor independence. 
Table 10. Analysis of University of Study Vs MAFR Enhancing Auditor Independence

\begin{tabular}{lrrrrrr}
\hline & SD & D & N & A & SA & Total \\
\hline UNIZULU & 5 & 0 & 8 & 49 & 88 & 150 \\
UKZN & 6 & 5 & 16 & 68 & 168 & 263 \\
Total & 11 & 5 & 24 & 117 & 256 & 413 \\
\hline
\end{tabular}

A consistently high percentage of respondents at both universities (UNIZULU: 91.3\% and UKZN: 89.7\%) that agree that MAFR would enhance auditor independence.

Table 11. Analysis of the Level of Study vs MAFR Enhancing Auditor Independence

\begin{tabular}{lrrrrrr}
\hline & SD & D & N & A & SA & Total \\
\hline 2 & 3 & 1 & 7 & 41 & 85 & 137 \\
3 & 5 & 4 & 14 & 60 & 131 & 214 \\
4 & 3 & 0 & 3 & 16 & 40 & 62 \\
Total & 11 & 5 & 24 & 117 & 256 & 413 \\
\hline
\end{tabular}

A consistently high percentage of respondents at different levels of study $(2: 91.9 \%, 3: 89.3 \%$ and 4 : 90.3\%) agreed that MAFR would enhance auditor independence.

Students were asked to provide additional comments on MAFR if they had any, particularly not covered in the questionnaire. Comments by respondents primarily emphasised their views on MAFR with some noting their reservations on its implementation. The majority of the comments were already covered by the questionnaire. Interestingly, the comments below are in line with the ongoing debate and mixed research outcomes on MAFR Ewelt-Knauer et al. (2013) and Junaidi et al. (2016), as while respondents show support for MAFR, some issues are raised as potential concerns, in line with current literature.

Respondents remarked that MAFR will have a positive outcome on auditor independence as it will; 1) Safeguard against the (or decrease) familiarity threat to independence, 2) Lead to improved professional scepticism and auditor independence, 3) Increase the focus of firms and auditors on ethical behaviour and compliance with principles in the code of conduct.

Some respondents mentioned the following possible negative outcomes of the implementation of MAFR affecting auditor independence, namely; 1 ) it will result in a lack of objectivity (with new auditors trying to impress their client), and 2) it will not result in any significant impact on independence as intended but will lead to increased audit risk and audit fees.

Respondents comment that MAFR has both positive and negative outcomes, with some noting that audit partner rotation is sufficient.

\section{Conclusions}

This section discusses a summary of our study, makes recommendations, suggests more research be conducted on MAFR and discusses limitations and delimitations for the study.

There is currently no consensus by different stakeholders and jurisdictions on whether or not the implementation of MAFR yields positive or negative outcomes, including auditor independence. Current auditing students, as future auditors, are a stakeholder in the profession and most of whom will be amongst audit teams implementing MAFR in South Africa. Based on this, this study identified the objective as being to determine whether, according to university students, the introduction and implementation of MAFR will enable the IRBA to meet the objective of improving auditor independence.

The literature on MAFR and independence reviewed highlighted the discourse that exists regarding the impact of MAFR. The role conflict theory was identified as possibly giving rise to independence issues and the need for MAFR due to the auditor's need to meet the expectations of the regulatory body (IRBA), various stakeholders which include management, shareholders and those external to their clients. The motivation for MAFR is debatable. This as some are of the opinion that the regulation is not the correct solution to the problem - if there is indeed a problem. Economic theories of regulation suggest the MAFR regulation may indeed be underpinned by public interests (business, economy, stakeholders, society, etc.), but could however be motivated by private interests (power, prestige, public standing, perception, etc. of the IRBA or interest groups).

A quantitative approach has been followed for the study. The population are auditing students at the universities of KwaZulu-Natal and Zululand, the two traditional residential universities in the province of KwaZuluNatal. Students (participants) were selected based on convenience, students who were in class on the day scheduled for data collection. Participants completed a questionnaire which was the instrument used to collect data. Results of the study are presented, analysed and discussed in section 4 . The section also discusses the validity and reliability 
tests performed to ensure the credibility of the study. A descriptive statistical analysis was presented as well as an analysis of the Pearson's correlation in relation to the impact on auditor independence.

Based on responses to questions 7 to 11, students perceive MAFR as having a positive impact on auditor independence. Students either agreed or strongly agreed with between $78.5 \%$ and $93.3 \%$ (and an average mean for all questions of 4.29) with statements, suggesting that the introduction of MAFR would improve independence. A total of $68.8 \%$ of students strongly agreed that tenure of above 10 years leads to a familiarity threat to independence, while $62 \%$ strongly agreed that MAFR would improve independence. Furthermore, positive moderate to strong relationships were found in the responses provided by students to all questions relating to independence, confirming the general view by respondents that the implementation of MAFR will improve auditor independence.

Student responses were found to be consistent across racial lines, age groups, the two universities and levels of study. On analysis of comments provided by students on their questionnaires (through one open question), however, students provided positive comments as well as notable potential negative consequences of MAFR. In conclusion, current university auditing students perceive the introduction and implementation of MAFR as having a positive impact on independence. This conclusion is consistent with Gates et al. (2006) who concluded that business and law university students consider MAFR to improve confidence in the reported information and perceived MAFR as having a positive impact on audited financial statements and audit quality.

\section{References}

AICPA. (2017). AICPA Response: Consultation Paper on MAFR (by IRBA).

Anis, A. (2014). Auditors' perceptions of audit firm rotation impact on audit quality in Egypt. Journal of Accounting \& Taxation, 6(1), 105-120.

Arel, B., Brody, R. G., \& Pany, K. (2005). Audit Firm Rotation and Audit Quality. The CPA Journal (Accounting \& Auditing), 75(1), 36-39.

Aschauer, E., \& Quick, R. (2018). Mandatory audit firm rotation and prohibition of audit firm - provided tax services $\square$ : Evidence from investment consultants ' perceptions. International Journal of Auditing, 22(2), 131-149. https://doi.org/10.1111/ijau.12109

Aslan, O. (2012). Mandatory Audit Firm Rotation $\square$ : A cure or a placeboロ? Tilburg University.

Bals, L., Schulze, H., Kelly, S., \& Stek, K. (2019). Purchasing and supply management (PSM) competencies: Current and future requirements. Journal of Purchasing and Supply Management, 25(5), 1-42.

Bamber, E. M., \& Iyer, V. M. (2007). Auditors' identification with their clients and its effect on auditors' objectivity. Auditing: A Journal of Practice \& Theory, 26(2), 1-24.

Blair, J., Czaja, R. F., \& Blair, E. A. (2014). Designing Surveys (3rd ed.). Sage Publications.

Church, B. K., Jenkins, J. G., Mccracken, S. A., Roush, P. B., \& Stanley, J. D. (2015). Auditor independence in fact: Research, regulatory, and practice implications drawn from experimental and archival research. Accounting Horizons American Accounting Association, 29(1), 217-238. https://doi.org/10.2308/acch50966

Cresswell, J. W. (2014). Research Design: Qualitative, Quantitative, And Mixed Method Approaches. Fourth Edition. Thousand Oaks.

Creswell, J. W. (2014). Educational Research: Planning, Conducting, and Evaluating Quantitative and Qualitative Research (P. A. Smith (ed.); 4th ed.). Pearson.

Daniels, B. W., \& Booker, Q. (2011). The effects of audit firm rotation on perceived auditor independence and audit quality. Research in Accounting Regulation, 23(1), 78-82. https://doi.org/10.1016/j.racreg.2011.03.008

Dezoort, F. T., \& Taylor, M. H. (2015). A public interest view of auditor independence: Moving toward auditor reliability when considering and promoting audit quality. American Accounting Association: Accounting and the Public Interest, 15(1), 53-63. https://doi.org/10.2308/apin-10498

Dhaliwal, D. S., Lamoreaux, P. T., Lennox, C. S., \& Mauler, L. M. (2015). Management influence on auditor selection and subsequent impairments of auditor independence during the Post-SOX period. Contemporary Accounting Research, 32(2), 575-607. https://doi.org/10.1111/1911-3846.12079

Ewelt-Knauer, C., Gold, A., \& Pott, C. (2013). Mandatory audit firm rotation: A review of stakeholder perspectives and prior research. Accounting in Europe, 1Q1), 27-41. https://doi.org/10.1080/17449480.2013.772717 
Floyd, J., \& Fowler, J. (2009). Survey Research Methods (L. Bickman \& D. J. Rog (eds.); 4th ed.). Sage Publications.

Garcia-Blandon, J., \& Argiles-Bosch, J. M. (2017). The interaction effects of firm and partner tenure on audit quality. Accounting and Business Research, 47(7), 810-830. https://doi.org/10.1080/00014788.2017.1289073

Garcia-Blandon, J., \& Argiles, J. M. (2015). Audit firm tenure and independence: A comprehensive investigation of audit qualifications in Spain. Journal of International Accounting, Auditing and Taxation, 24, 82-93. https://doi.org/10.1016/j.intaccaudtax.2015.02.001

Gates, S. K., Jordan Lowe, D., \& Reckers, P. M. J. (2006). Restoring public confidence in capital markets through auditor rotation. Managerial Auditing Journal, 22(1), 5-17. https://doi.org/10.1108/02686900710715611

Hair, J. F., Money, A. H., Samouel, P., \& Page, M. (2007). Research Methods for Business. John Wiley and Sons.

Harber, M. (2016). Exploring a South African Solution to an International Concern over Auditor Independence: The South African Audit Profession's Opinions with Regard to Mandatory Audit Firm Rotation. University of Cape Town Senate.

Harber, M., \& Maroun, W. (2020). Mandatory audit firm rotation: a critical composition of practitioner views from an emerging economy. Managerial Auditing Journal, 35(7), 861-896.

Hodge, F. D. (2003). Investors' perceptions of earnings quality, auditor independence, and the usefulness of audited financial information. Accounting Horizons, 17(1), 37-48.

Hofstee, E. (2006). Constructing a Good Dissertation: A Practical Guide to Finishing a Masters, MBA or PhD on Schedule (1st ed.). Exactica.

Hohenfels, D. (2016). Auditor tenure and perceived earnings quality. International Journal of Auditing, 20(3), 224238. https://doi.org/10.1111/ijau.12069

Howe, N., \& Strauss, W. (1993). 13th Gen: Abort, Retry, Ignore, Fail?(1st ed.). Vintage. https://doi.org/loc?

Hussey, R. (1999). The familiarity threat and auditor independence. Corporate Governance: An International Review, 7(2), 190-197. https://doi.org/10.1111/1467-8683.00146

IRBA. (2009). Code of Professional Conduct for Registered Auditors (Issue July).

IRBA. (2017a). Frequently asked questions: Strengthening auditor independence to enhance public investor protection through mandatory audit firm rotation (MAFR). IRBA. irba.co.za/news-headlines/pressreleases/the-irba-announces-measures-to-strengthen-auditor-independence-and-enhance-investorprotection

IRBA. (2017b). Frequently asked questions on MAFR.

IRBA. (2017c). IRBA Inspections Report shows decline in audit quality. IRBA. https://www.irba.co.za/newsheadlines/press-releases/irba-inspections-report-shows-decline-in-audit-quality

Junaidi, Hartono, J., Suwardi, E., Miharjo, S., \& Hartadi, B. (2016). Does auditor rotation increase auditor independence? Gadjah Mada International Journal of Business, 18(3), 315-336.

Khan, A. W., \& Subhan, Q. A. (2019). Impact of board diversity and audit on firm performance. Management, Cogent Business, 6(1), 1-16.

Kumar, D. M. (2012). Get along with quantitative research process. International Journal of Research in Management, 2(2), 15-29.

Malsch, B., Tremblay, M., \& Gue, H. (2015). On the operational reality of auditors' independence: Lessons from the Field. Auditing: A Journal of Practice \& Theory, 34(2), 201-236. https://doi.org/10.2308/ajpt-50905

Ottaway, J. (2013). Improving Auditor Independence in Australia: Is "Mandatory Audit Firm Rotation" The Best Option?

Pearson, M. A. (1987). Auditor Independence Deficiencies \&amp; Alleged Audit Failures. Journal of Business Ethics, 6(4), 281-287.

Pew Research Center. (2010). Pew Research: The Millennials / Confident. Connected. Open to Change. Www.Pewsocialtrends.Org.

Quick, R. (2012). EC green paper proposals and audit quality. Accounting in Europe, 9(1), 17-38. https://doi.org/10.1080/17449480.2012.664398 
Reid, L. C., \& Carcello, J. V. (2017). Investor reaction to the prospect of mandatory audit firm rotation. The Accounting Review, 92(1), 183-211. https://doi.org/10.2308/accr-51488

Rizzo, J. R., House, R. J., \& Lirtzman, S. (1970). Role conflict and ambiguity in complex organizations. Administrative Science Quarterly, 15(2), 150-163.

Ruiz-Barbadillo, E., Gómez-Aguilar, N., \& Carrera, N. (2009). Does mandatory audit firm rotation enhance auditor independence? Evidence from Spain. Auditing, 28(1), 113-135. https://doi.org/10.2308/aud.2009.28.1.113

SAICA. (2016). Competency Framework Detailed Guidance for the Academic Programme: Competencies of a $C A(S A)$ at the point of the Initial Test of Competence (ITC) (assessment of core technical knowledge) Effective date January 2018 (Issue January).

SAICA. (2017). Saica submission to Parliament's Standing Committee on Finance.

SAICA Indaba. (2016). SAICA MAFR Indaba (Issue November).

Said, K., \& Khasharmeh, H. (2014). Auditors ' perceptions on impact of mandatory audit firm rotation on auditor independence - Evidence from Bahrain. Journal of Accounting and Taxation, 6, 1-18. https://doi.org/10.5897/JAT2013.0127

Saunders, M., Lewis, P., \& Thornhill, A. (2009). Research Methods for Business Students (5th ed.). Pearson Education.

Stern, C. (2015). The Controversy of Mandatory Audit Firm Rotation: Has Quantitative Accounting Research Misinformed us about the Relationship between Audit Tenure and Audit Quality? University at Albany, State University of New York Scholars Archive.

Svanberg, J., \& Öhman, P. (2015). Auditors' identification with their clients: Effects on audit quality. British Accounting Review, 47(4), 395-408. https://doi.org/10.1016/j.bar.2014.08.003

Tanlu, L., Moore, D. A., \& Bazerman, M. H. (2003). The Failure of Auditor Independence: Cognitive, Structural , Legislative, and Political Causes. Semantic Scholar, 1-30. https://www.semanticscholar.org/paper/TheFailure-of-Auditor-Independence-\%3A-Cognitive-\%2C-\%2C-TanluMoore/fbadb80794e1f0f46868d3a0f1e1131b93852ded\#paper-header

Teck-Heang, L., \& Ali, A. M. (2008). The evolution of auditing: An analysis of the historical development. In Journal of Modern Accounting and Auditing (Vol. 4, Issue 12).

Tepalagul, N., \& Lin, L. (2015). Auditor independence and audit quality: A literature review. Journal of Accounting, Auditing \& Finance, 301), 101-121. https://doi.org/10.1177/0148558X14544505

Tysiac, K. (2014). Mandatory audit firm rotation rules published in EU. Journal of Accountancy.

Walker, S., Gibbins, J., Paes, P., Adams6, A., Chandratilake, M., Gishen, F., Lodge, P., Wee, B., \& Barclay, S. (2017). Palliative care education for medical students: Differences in course evolution, organisation, evaluation and funding: A survey of all UK medical schools. Palliative Medicine, 31(6), 575-581.

Zhang, Y. (Elli), Hay, D., \& Holm, C. (2016). Non-audit services and auditor independence: Norwegian evidence. Cogent Business \& Management, 3(1), 1-19. 